\title{
Validation of the multiplex PCR for identification of Brucella spp.
}

\author{
Validação da técnica de PCR multiplex para identificação de Brucella spp.
}

\author{
Lívia de Lima Orzil ${ }^{\mathrm{I}}$ Ingred Sales Preis $^{\mathrm{I}}$ Iassudara Garcia de Almeida $^{\mathrm{I}}$ \\ Patrícia Gomes de Souza ${ }^{I}$ Paulo Martins Soares FilhoI \\ Fabrício Barcelos Jacinto ${ }^{\text {II }}$ Antônio Augusto Fonseca Júnior ${ }^{*}$
}

\section{ABSTRACT}

A multiplex PCR technique for detection of Brucella spp. in samples of bacterial suspension was validated as a complementary tool in the diagnosis of the disease. This technique allows the characterization of the agent without performing biochemical tests, which greatly reduces the time for a final diagnosis, and provides more security for the analyst by reducing the time of exposure to microorganisms. The validation was performed in accordance with the Manual of Diagnostic Tests from $O I E$ (2008) and following the requirements present in the ABNT NBR ISO/IEC 17025:2005. The mPCR validated in this study identified the different species of Brucella (Brucella abortus, B. suis, $\boldsymbol{B}$. ovis e B. melitensis) of bacterial suspension obtained from the slaughterhouse samples, as well as distinguished the biovars (1, 2 e 4; 3b, 5, 6 e 9) of $\boldsymbol{B}$. abortus in grouped form and differentiated the field strains from vaccine strains, as a quick, useful and less expensive technique in diagnosis of brucellosis in Brazil.

Key words: Brucellosis, molecular identification, zoonosis, Brucella, multiplex PCR.

\section{RESUMO}

Validou-se neste trabalho uma técnica de PCR Multiplex ( $m P C R$ ) para detecção de Brucella spp. em amostras de suspensão bacteriana, como ferramenta complementar no diagnóstico da doença. Esta técnica possibilita a caracterização do agente sem que seja necessária a realização de testes bioquímicos, o que diminui consideravelmente o tempo para o diagnóstico final, além de oferecer mais segurança ao analista ao diminuir o tempo de exposição ao agente infecioso. A validação foi realizada de acordo com o Manual de Testes de Diagnósticos da OIE (2008), seguindo as exigências presentes na norma de qualidade da ABNT NBR ISO/IEC 17025:2005. A mPCR validada neste trabalho identificou as diferentes espécies de Brucella (Brucella abortus, B. suis, B. ovis e B. melitensis) em suspensão bacteriana, obtidas a partir de amostras de frigorifico. Além disso, discriminou os biovares (1, 2 e 4; 3b, 5, 6 e 9) de B. abortus, de forma agrupada e diferenciou cepa vacinal de cepa de campo, sendo esta uma técnica rápida, útil e de menor custo para o auxílio no diagnóstico de brucelose no Brasil.

Palavras-chave: Brucelose, identificação molecular, zoonose, Brucella, PCR multiplex.

\section{INTRODUCTION}

Brucellosis is an infectious zoonotic disease of chronic evolution and global distribution listed as notifiable by the World Organization for Animal Health (OIE, 2008). The species of greatest economic interest are Brucella abortus, Brucella melitensis, Brucella suis, Brucella canis and Brucella ovis, the latter being the only one of those species that do not cause disease in humans (NIELSEN \& DUNCAN, 2000; GALIŃSKA \& ZAGÓRSKI, 2013). In infected animals, the main clinical signs are linked to reproductive problems such as retained placenta, abortion and birth of weak calves which lead to major economic losses, especially in cattle herds (LAGE et al., 2009).

Brazilian law provides guidelines for indirect tests (serologic tests) using the Buffered Acidified Antigen (BAA) test as a screening test and 2-Mercaptoethanol (2-ME) as a confirmatory test, but only in live animals (BRASIL, 2006). Thus, to

\footnotetext{
IMinistério da Agricultura, Pecuária e Abastecimento (MAPA), Pedro Leopoldo, MG, Brasil. E-mail: antonio.a.fonsecajr@gmail.com. ${ }^{*}$ Corresponding author.

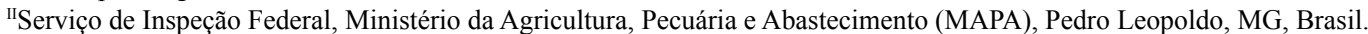


reach the final characterization of the agent, there is a long and laborious process of bacterial isolation that involves the manipulation of highly pathogenic bacterial colonies, which puts the analyst involved at risk (ALTON et al., 1975). Polymerase chain reaction (PCR) is an important aid in the diagnosis of brucellosis, making it especially useful in the process of bacterial identification due to factors such as high sensitivity and specificity, as well as to increase the biosecurity as it reduces time of exposure of the analyst to the infectious agent. The exposure time is less due to less manipulation of the agent, as biochemical tests are no longer necessary. This is important because, of all reported cases of human brucellosis, $2 \%$ infection are associated with laboratory work (COLLINS, 1983), with an attack rate of 30 to $100 \%$ (ERGÖNÜL et al., 2004), including a severe case recorded in Brazil (RODRIGUES et al., 2013).

Thus, it becomes important the validation of a safest alternative to the diagnosis of brucellosis. Molecular results are obtained in a short period of time, they are also relatively simple, involve lower costs when compared to bacterial isolation and the infectious agent can be inactivated (YU \& NIELSEN, 2010). This work aimed to validate a multiplex PCR (mPCR) for identification of different species of Brucella spp. in samples of bacterial suspension in accordance with the Manual of Diagnostic Tests (OIE, 2008). This technique was introduced into the routine of the Laboratório Nacional Agropecuário de Minas Gerais (Lanagro/MG) as an aid in the official diagnosis of brucellosis in the country.

According to the OIE (2008), validation is a process that determines the ability of a given test developed properly, optimized and standardized for a purpose. Thus, validation must guarantee, through experimental studies, that the method meets the requirements of the analytical applications, ensuring the reliability of the results. This is important for proper accreditation of the laboratory in ISO/IEC 17025:2005 for quality insurance applicable to calibration and testing laboratories. The objective of this study is to validate a technique for diagnosis of brucellosis faster, safer and less costly to be used in routine LANAGRO/MG.

\section{MATERIAL AND METHODS}

The MPCR used was based on previous studies by BRICKER \& HALLING (1994), with modifications and inclusion of primers designed by LÓPEZ-GOÑI et al. (2008). This method, called AMOS (a short for abortus, melitensis, ovis and suis)
PCR, has as principle the amplification of $i$ s 711 region by PCR, which enables to differentiate the species of Brucella, since the number of repetitive copies of the genetic element is unique for each species or biovar with different positioning in the genome. Different primers, specific for the various Brucella species (B. abortus, B. abortus $\mathrm{S} 19$, B. melitensis, B. suis and $\boldsymbol{B}$. ovis), generate PCR products of different sizes, approximately 498 bp for B. abortus (biovars 1, 2 and 4), 537bp for B. abortus S19, 590bp for $\boldsymbol{B}$. abortus field strain, $731 \mathrm{bp}$ for $\boldsymbol{B}$. melitensis, $976 \mathrm{bp}$ for $\boldsymbol{B}$. ovis, and 285bp for B. suis (Figure 1). The primers sequences are shown in table 1 and the profile according to the primers used are shown in table 2 .

We used a pair of primers as internal for the mPCR which amplifies the region responsible for the expression of the $16 \mathrm{~S}$ bacterial ribosomal RNA resulting in a $800 \mathrm{bp}$ amplified product (BRICKER et al., 2003). Samples of B. abortus, B. abortus S19, B. abortus biovar 1, B. abortus biovar 3, B. melitensis and $\boldsymbol{B}$. suis, provided by Lanagro/MG, were used during the validation process of the mPCR as positive controls. Samples suspended in saline were inactivated at $60^{\circ} \mathrm{C}$ for 1 hour. The inactivated bacterial suspension was used for PCR without special methods or kits for DNA extraction.

Different species of bacteria were used as negative control. Samples of Trueperella pyogenes were collected from the primary isolation in the Laboratory of Diagnostics of Bacterial Diseases in Lanagro/MG. Because of the similarity between the morphological characteristics of this

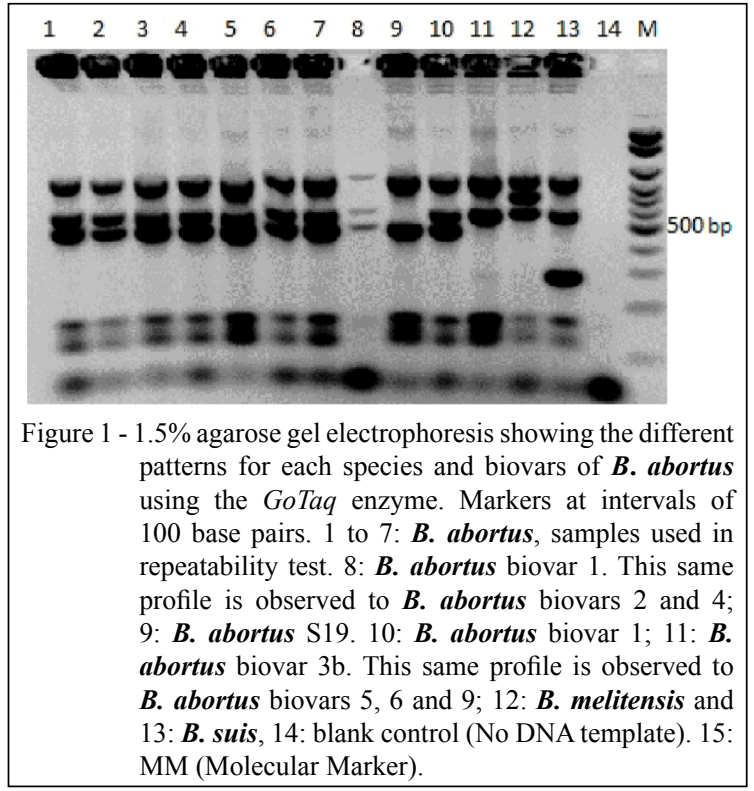


Table 1 - DNA sequence of the primers used in the validation of the mPCR, gene target and reference.

\begin{tabular}{|c|c|c|c|}
\hline Primer & DNA sequence $\left(5^{\prime}-3^{\prime}\right)$ & Gene target & Reference \\
\hline Bru-AMOS-Ab & GAC GAA CGG AAT TTT TCC AAT CCC & $\begin{array}{l}\text { alpha-ketoglutarate- } \\
\text { dependent dioxygenase }\end{array}$ & BRICKER \& HALLING, 1994 \\
\hline Bru-AMOS-Me & AAA TCG CGT CCT TGC TGG TCT GA & hypothetical protein & BRICKER \& HALLING, 1994 \\
\hline Bru-AMOS-Ov & CGG GTT CTG GCA CCA TCG TCG & $\begin{array}{l}\text { TRAP transporter solute } \\
\text { receptor, TAXI family } \\
\text { protein" }\end{array}$ & BRICKER \& HALLING, 1994 \\
\hline Bru-AMOS-Su & GCG CGG TTT TCT GAA GGT TCA GG & $\begin{array}{l}\text { indole-3-glycerol } \\
\text { phosphate synthase }\end{array}$ & BRICKER \& HALLING, 1994 \\
\hline Bru-AMOS-IS711: & TGC CGA TCA CTT AAG GGC CTT CAT & is 711 & BRICKER \& HALLING, 1994 \\
\hline 16s.Universal.800F: & GTG CCA GCA GCC GCC GTA ATA C & $16 \mathrm{~S}$ & BRICKER et al.,2003 \\
\hline 16s.Universal.800R & TGG TGT GAC GGG CGG TGT GTA CAA G & $16 \mathrm{~S}$ & BRICKER et al.,2003 \\
\hline Bru-BMEii0428F & GCC GCT ATT ATG TGG ACT GG & eriD & LÓPEZ-GOÑI et al., 2008 \\
\hline Bru-BMEii0428R & AAT GAC TTC ACG GTC GTT CG & eriD333 & LÓPEZ-GOÑI et al., 2008 \\
\hline
\end{tabular}

bacterium with Brucella, the use of $\boldsymbol{T}$. pyogenes was important during the isolation process from suspicious material submitted to the diagnosis of brucellosis. Other samples were also used such as Rhodococcus equi, Salmonella enterica, Staphylococcus aureus and Escherichia coli.

Bacterial suspensions isolated from 164 samples of bovine tissues collected from slaughterhouses were used for validation. The bacterial strains were isolated using tryptose agar with $5 \%$ bovine serum and incubation performed at $37+-2^{\circ} \mathrm{C}$ with $5-10 \% \quad \mathrm{CO}_{2}$. Typical colonies of Brucella spp. were selected and subjected to biochemical tests (catalase, oxidase, urease, citrate, and nitrate reduction). Confirmation of species and biovars of Brucella spp. were determined by growth tests in an atmosphere of $\mathrm{CO}_{2}$ and $\mathrm{O}_{2}$, acriflavine agglutination test, $\mathrm{H}_{2} \mathrm{~S}$ production, growth in the presence of thionine $\left(20 \mathrm{mg} \mathrm{mL}^{-1}\right.$ and $\left.40 \mathrm{mg} \mathrm{mL}^{-1}\right)$ and basic fuchsin $\left(20 \mathrm{mg} \mathrm{mL}^{-1}\right)$ and forward assemblage anti-A serum and anti-F (ALTON et al., 1988). The colonies diluted in saline from the primary isolation were inactivated in a water bath at $65^{\circ} \mathrm{C}$ for an hour and sent for realization of $\mathrm{mPCR}$.

All isolates from the primary isolation were submitted to biochemical tests. One hundred and twelve isolates had a certificate of origin according to ISO 17025 (data such as biovars and the Brazilian state of the sample origin are listed in table 3). The remainder was collected previous to accreditation and had no certificate of origin but was submitted to biochemical tests so it could be certified as Brucella.

The determination of limit of detection (LOD) was performed on ten-point decimal dilutions of a sample of B. abortus. The dilutions were tested in triplicate in the mPCR. The LOD was determined by the lowest concentration at which the agent was detected in all replicates. For the repeatability tests, it was used seven Brucella spp. and seven bacteria belonging to others genera previously cited as negative controls. These tests were carried out in three days by two analysts. Regarding the reproducibility, 20 samples were used in the mPCR with three high performance enzymes from different manufacturers:

Table 2 - Electrophoresis profiles of Brucella spp. observed according to the primers used on mPCR.

\begin{tabular}{|c|c|c|c|c|c|c|}
\hline Primers & B. abortus S19 & B. abortus 1,2 e 4 & B. abortus 3, 5, 6 e 9 & B. melitensis & B. suis & B. ovis \\
\hline Bru-AMOS-Ab is 711 & + & + & - & - & - & - \\
\hline Bru-AMOS-Me is 711 & - & - & - & + & - & - \\
\hline Bru-AMOS-Ov is 711 & - & - & - & - & - & + \\
\hline Bru-AMOS-Su is711 & - & - & - & - & + & - \\
\hline 16s.Universal & + & + & + & + & + & + \\
\hline Bru-BMEii & - & + & + & + & + & + \\
\hline
\end{tabular}


Table 3 - List of biovars of Brucella abortus identified in bacterial isolation and their Brazilian State.

\begin{tabular}{lcccc}
\hline Brazilian State & B. abortus 1 & B. abortus 2 & B. abortus 3 & B. abortus 4 \\
\hline Pará & 18 & 45 & 10 & 1 \\
Mato Grosso & 10 & 2 & 0 & 0 \\
Mato Grosso do Sul & 1 & 1 & 0 & 0 \\
Rondônia & 2 & 1 & 2 & 0 \\
Tocantins & 2 & 1 & 0 & 0 \\
Rio Grande do Sul & 13 & 51 & 14 & 1 \\
Total & 46 & & \\
\hline
\end{tabular}

GoTaq (Promega, USA) Platinum Taq (Invitrogen, USA) and Jump Start (Sigma Aldrich, USA).

\section{RESULTS AND DISCUSSION}

\section{Standardization}

The best concentrations for AMOS PCR were defined by trial and error as $0.20 \mathrm{pmol} \mathrm{uL}^{-1}$ of each primer, $0.05 \mathrm{U} \mathrm{uL}^{-1}$ GoTaq (Promega, USA), $1.2 \mathrm{mmol}$ $\mathrm{L}^{-1} \mathrm{MgCl}_{2}, 0.25 \mathrm{mmol} \mathrm{L}^{-1} \mathrm{dNTP}$, and $1 \mathrm{X}$ Buffer Green (Promega, USA ) to a final volume of $25 \mu \mathrm{L}$ with $2.5 \mu \mathrm{L}$ of this DNA at 10 to $100 \mathrm{ng} \mu \mathrm{L}^{-1}$. The reaction went through a period of denaturation at $95^{\circ} \mathrm{C}$ for $3 \mathrm{~min}$, followed by 35 cycles at $95^{\circ} \mathrm{C}$ for $75 \mathrm{~s}, 80 \mathrm{~s}$ and $55.5^{\circ} \mathrm{C}$ by $72^{\circ} \mathrm{C}$ for $80 \mathrm{~s}$ and a final extension cycle at $72^{\circ} \mathrm{C}$ for $5 \mathrm{~min}$. In order to confirm the PCR results, products were visualized on $1.5 \%$ agarose gel electrophoresis with 60 minutes running time at $100 \mathrm{~V}$.

All 164 samples submitted to bacterial biochemical assays were concordant in the mPCR results. In EWALT \& BRICKER (2000), the number of samples used in the validation of a simplified AMOS PCR was 231, which is a close number to the present research.

\section{Limit of detection}

The LOD found was $0.35 n g \mathrm{~L}^{-1}$. This concentration is considered sufficient for this particular test, given the high number of bacteria in each colony obtained during the isolation process. The amount of DNA is so high that some samples may need to be diluted for a better visualization of each PCR band in gel electrophoresis (DATA NOT SHOWN). The main concern is to obtain a better test specificity, so the LOD is important only to clarify the minimum amount of DNA recommended to be used in the PCR.

\section{Repeatability}

The result of the repeatability of tests conducted by two analysts was considered satisfactory as all samples had the same molecular profiles defined during test standardization. Repeatability is the ability of a method to produce the same response with different operators in the same laboratory. It is therefore important to understand the factors that influence the outcome of a particular technique in order to ensure its reliability.

Reproducibility

The variables used in the reproducibility test did not show satisfactory results since it was not observed the pattern of bands expected using those enzymes even though various concentrations of enzymes or different $\mathrm{MgCl}_{2}$ concentrations have been tested. Therefore, enzymes Taq Platinum and Jump Start were excluded as an option in molecular test to identify Brucella spp. by this mPCR (Figures 2 and 3).

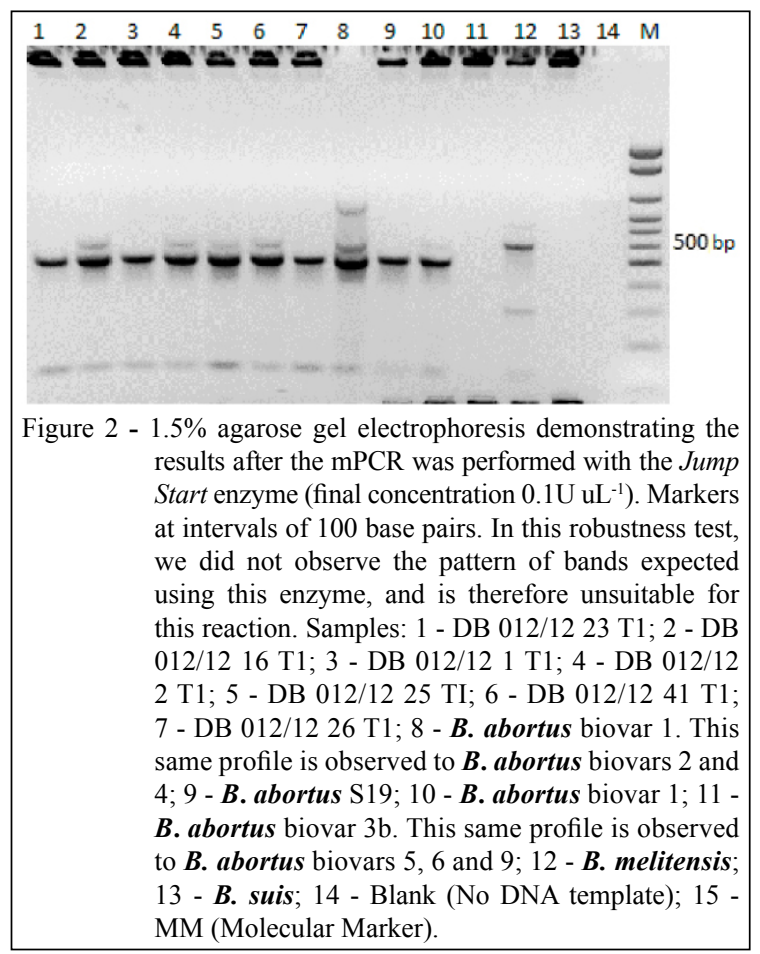




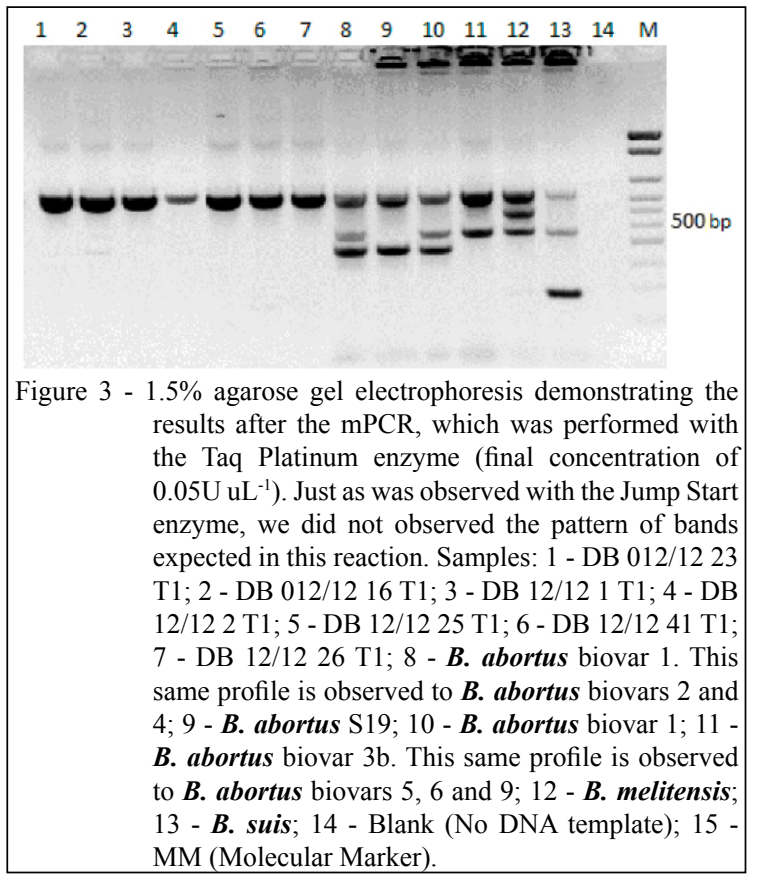

Not even the differing changes in the concentrations of these enzymes were enough to increase efficiency in the reaction. This type of result is common since different enzymes have different activities depending on the conditions in which they are used (TERPE, 2013). Thus, in this mPCR, the most efficient enzyme was GoTaq (Promega, USA).

The mPCR validated in the present research has identified different Brucella species and was able to discriminate the vaccine strain S19, field strain and different groups of biovars found in Brazil (MINHARRO et al., 2013). Originally described AMOS PCR can not detect biovars 3, 5, 6 and 9 and does not any internal control for DNA extraction and PCR inhibition, except when working with differentiation of vaccine samples (BRICKER \& HALLING, 1995). Discriminating biovars is an important step as it contributes significantly to future epidemiological studies. The presence of an extraction control to verify the possibility of PCR inhibition is also fundamental to the process of quality assurance and to determine if a negative result occurs due to the absence of a specific Brucella DNA or to the presence of inhibitors or lack of DNA (RUSSO \& MALNATI, 2014).

The mPCR is a low-risk diagnostic technique because there is only the manipulation of genetic material from the agent in the laboratory. This is important in the case of a highly pathogenic microorganism to men. Brucellosis is one of the most commonly acquired diseases in laboratories due to the manipulation of the agent in culture media (FIORI et al., 2000). The bacterial isolation for diagnosis of brucellosis requires a well structured laboratory with biosafety level 3 and highly qualified staff for handling these microorganisms. We estimated that the time taken for bacterial characterization by molecular method proposed in this research is five times lower when compared to the bacterial isolation method. In order to overcome the disadvantages mentioned, the introduction of molecular diagnostic technique substantially reduces handling of the colonies, which reduces the risk of contamination and the cost for determining the final diagnosis (YU \& NIELSEN, 2010).

The method validated according to international guidelines in this research represents an important advance to biosafety and speed in the diagnostic of Brucella spp. It has also advantages compared to the original molecular methods described in literature as it is able to distinguish the biovars of $\boldsymbol{B}$. abortus in grouped form.

\section{ACKNOWLEDGEMENTS}

We thank to Conselho Nacional de Desenvolvimento Científico e Tecnológico (CNPq) for the support with research scholarship.

\section{REFERENCES}

ALTON, G.G. et al. Laboratory techniques in brucellosis. Geneva, Switzerland: World Health Organization Monograph Series, 1975. N.55, p.11-63.

ALTON, G.G. et al. Techniques for the brucellosis laboratory. Paris: Institut National de la Recherche Agronomique, 1988. 190p.

BRASIL - PROGRAMA NACIONAL DE CONTROLE E ERRADICAÇÃO DA BRUCELOSE E DA TUBERCULOSE ANIMAL (PNCEBT). Manual técnico - Ministério da Agricultura, Pecuária e Abastecimento. Brasília, 2006. 188p.

BRICKER, B.J.; HALLING, S.M. Differentiation of Brucella abortus bv. 1, 2, and 4, Brucella melitensis, Brucella ovis, and Brucella suis bv. 1 by PCR. Journal of Clinical Microbiology, v.32, n.11, p.2660-2666, 1994. Available from: $<\mathrm{http}: / / \mathrm{jcm}$.asm. org/content/32/11/2660.full.pdf $>$. Accessed: Jan. 20, 2014.

BRICKER, B.J.; HALLING, S.M. Enhancement of the Brucella AMOS PCR assay for differentiation of Brucella abortus vaccine strains S19 and RB51. Journal of Clinical Microbiology, v.33, n.6, p.1640-1642, 1995. Available from: <http://www.ncbi.nlm.nih.gov/ pmc/articles/PMC228233/pdf/331640.pdf>. Accessed: Jan. 15, 2014.

BRICKER, B.J. et al. Evaluation of the Brucella abortus species-specific polymerase chain reaction assay, an

Ciência Rural, v.46, n.5, mai, 2016. 
improved version of the Brucella AMOS polymerase chain reaction assay for cattle. Journal of Veterinary Diagnostic Investigation, v.15, n.4, p.374-378, 2003. Available from: <http://vdi.sagepub.com/content/15/4/374. long >. Accessed: Jan. 20, 2014.

COLLINS, CH. Laboratory-acquired infections. London: Butterworths; 1983.

ERGÖNÜL, Ö. et al. Analysis of risk factors for laboratoryacquired Brucella infections. Journal of Hospital Infection, v.56, n.3, p.223-227, 2004.

EWALT, D.R.; BRICKER, B.J. Validation of the abbreviated Brucella AMOS PCR as a rapid screening method for differentiation of Brucella abortus field strain isolates and the vaccine strains, 19 and RB51. Journal of Clinical Microbiology, v.38, n.8, p.3085-3086, 2000. Available from: <http://jcm.asm. org/content/38/8/3085.long >. Accessed: Mar. 10, 2014.

FIORI, P.L. et al. Brucella abortus infection acquired in microbiology laboratories. Journal of Clinical Microbiology, v.38, n.5, p.2005-2006, 2000. Available from: <http://jcm.asm. org/content/38/5/2005.long>. Accessed: Mar. 10, 2014.

GALIŃSKA, E.M.; ZAGÓRSKI, J. Brucellosis in humans etiology, diagnostics, clinical forms. Annals of Agricultural and Environmental Medicine, v.20, n.2, p.233-238, 2013. Available from: <http://aaem.pl/fulltxt.php?ICID=1052322>. Accessed: Jan. 15, 2014

LAGE, A.P. et al. Brucelose bovina: uma atualização. Revista Brasileira de Reprodução Animal, v.32, n.3, p.202-212, 2009. Available from: <http://www.cbra.org.br/pages/publicacoes/ rbra/download/RB206\%20Lage\%20vr2\%20pag202-212.pdf>. Accessed: Mar. 10, 2014.

LÓPEZ-GOÑI, I. et al. Evaluation of a multiplex PCR assay (Bruce-ladder) for molecular typing of all Brucella species, including the vaccine strains. Journal of Clinical Microbiology, v.46, n.10, p.3484-3487, 2008. Available from: <http://jcm.asm. org/content/46/10/3484.long>. Accessed: Jan. 20, 2014.

MINHARRO, S. et al. Biotyping and Genotyping (MLVA16) of Brucella abortus isolated from cattle in Brazil, 1977 to 2008. PLoS ONE, v.8, n.12, p.1-7, 2013. Available from: $<$ http://journals.plos.org/plosone/article?id=10.1371/journal. pone.0081152>. Accessed: Mar. 10, 2014

NIELSEN, K.; DUNCAN, J.R. Animal brucellosis. In: BLASCO, J.M. Brucella ovis. Florida: CRC, 2000.

OIE (WORLD ORGANIZATION FOR ANIMAL HEALTH). Manual of diagnostic tests and vaccines for terrestrial animal. 6.ed. Paris, 2008. V.1.

RODRIGUES, A.L. et al. Outbreak of laboratory-acquired Brucella abortus in Brazil: a case report. Revista da Sociedade Brasileira de Medicina Tropical, v.46, n.6, p.791-794, 2013. Available from: <http://www.scielo.br/scielo.php?script=sci arttext\&pid=S0037-86822013000600791\&lng=en\&nrm=iso\&tl ng=en>. Accessed: Mar. 10, 2014.

RUSSO, D.; MALNATI, M.S. Absolute quantification of viral DNA: the quest for perfection. Methods in Molecular Biology, v.1160, p.75-86, 2014. Available from: <http://link. springer.com/protocol/10.1007\%2F978-1-4939-0733-5_7>. Accessed: Mar. 10, 2014.

TERPE, K. Overview of thermostable DNA polymerases for classical PCR applications: from molecular and biochemical fundamentals to commercial systems. Applied Microbiology and Biotechnology, v.97, p.10243-10254, 2013. Available from: $<$ http://link.springer.com/article/10.1007\%2 Fs00253-013-5290-2>. Accessed: Jan. 15, 2014.

YU, W.L; NIELSEN, K. Review of detection of Brucella sp. by polymerase chain reaction. Croatian Medical Journal, v.4, n.51, p.306-313, 2010. Available from: <http://www.ncbi.nlm. nih.gov/pmc/articles/PMC2931435/>. Accessed: Jan. 20, 2014. 